\begin{tabular}{|l|l|l||}
\hline \multicolumn{2}{|c|}{ PublisherInfo } \\
\hline \hline PublisherName & $:$ & BioMed Central \\
\hline \hline PublisherLocation & $:$ & London \\
\hline \hline PublisherImprintName & $:$ & BioMed Central \\
\hline \hline
\end{tabular}

\title{
Intravenous dofetilide vs amiodarone
}

\begin{tabular}{|l|l|l||}
\hline \multicolumn{2}{|c|}{ ArticleInfo } \\
\hline \hline ArticleID & $:$ & 50 \\
\hline \hline ArticleDOI & $:$ & $10.1186 /$ cvm-2001-72003 \\
\hline \hline ArticleCitationID & $:$ & 72003 \\
\hline \hline ArticleSequenceNumber & $:$ & 29 \\
\hline \hline ArticleCategory & $:$ & Paper Report \\
\hline \hline ArticleFirstPage & $:$ & 1 \\
\hline \hline ArticleLastPage & $:$ & 3 \\
\hline \hline & & RegistrationDate : 2001-10-17 \\
ArticleHistory & $:$ & Received \\
\hline ArticleCopyright & $:$ & Biomed Central Ltd2001 \\
\hline \hline ArticleGrants & $:$ & \\
\hline \hline
\end{tabular}




\begin{tabular}{|l|l|l|}
\hline ArticleContext & $:$ & 1306322 \\
\hline
\end{tabular}

Niall Mulvahill, ${ }^{\text {Aff1 }}$

Corresponding Affiliation: Aff1

Aff1 Freeman Hospital, Newcastle Upon Tyne, UK

\section{Keywords}

Class III drugs, medical cardioversion, torsades de pointes

\section{Context}

This paper describes acute chemical cardioversion of atrial fibrillation and flutter to sinus rhythm.

This research was undertaken to investigate further the use of dofetilide for acute cardioversion of atrial fibrillation and flutter.

\section{Significant findings}

Dofetilide, a class III antiarrhythmic, restored sinus rhythm in $35 \%$ of patients, $3 \mathrm{~h}$ after a $15 \mathrm{~min}$ infusion in comparison to conversion rates of $4 \%$ for amiodarone and $4 \%$ for placebo. The duration of atrial arrhythmia did not influence conversion rates. Treatment with dofetilide was associated with an $8 \%$ incidence of torsadea de pointes.

\section{Comments}

I found this article interesting because the effectiveness of dofetilide in cardioverting atrial fibrillation or flutter is not dependent on the duration of flutter, in contrast to flecainide and propfenone.

Possible implications of these findings are that a short intravenous infusion of dofetilide may be used for the conversion of long-standing atrial fibrillation or the conversion of atrial flutter; however, because of the incidence of torsades de pointes, continuous ECG monitoring is required. 


\section{Methods}

A meta-analysis of the published data to date reveals a $25 \%$ success rate for dofetilide in converting atrial fibrillation and a $65 \%$ success rate in converting atrial flutter.

\section{Additional information}

\section{References}

1. Bianconi L, Castro A, Dinelli M, Alboni P, Pappalardo A, Santini M: Intravenous dofetilide versus amiodarone for acute termination of atrial fibrillation and flutter. Eur Heart J 2000, 21:1265-1273. Eur Heart J. 2000, 21: 1265-1273.

This PDF file was created after publication. 